\title{
The Influence of Project Based Learning (PJBL) Learning Model on Spatial Thinking Ability in Class X Geography Learning Eyes in SMA PGRI 2 Palembang
}

\author{
Ramayana Dwi Putri \\ ramayanadwip28@gmail.com \\ Geography Education University PGRI Palembang
}

\begin{abstract}
ABSTRAK
One of the goals of learning geography is to give students the ability to think spatially. But based on observations in the field, it shows that students' spatial thinking skills have not shown maximum results. This study aims to determine the effect of the Project Based Learning (PJBL) learning model on spatial thinking skills in class $X$ geography subjects at SMA PGRI 2 Palembang. To determine the effect of Project Based Learning (PJBL) on spatial thinking skills, the researcher used the Experimental method.

Based on the results of data analysis and discussion on the effect of Project Based Learning (PJBL) learning models on spatial thinking skills in class $X$ geography subjects at SMA PGRI 2 Palembang, it can be concluded that the results of the average data analysis results of the students' experimental class spatial thinking test 76.02 while the control class averages 61.72. Based on the results of the t-test obtained thitung $=8.43$ then compared with $t_{\text {table }}=1.66$, then $t_{\text {count }}>t_{\text {table }}$ is $8.43>1.66$. These results prove that there is a significant influence between the Project Based Learning (PJBL) learning model on spatial thinking skills in class $X$ geography subjects at SMA PGRI 2 Palembang.
\end{abstract}

Keywords: Learning Model, Project Based Learning (PJBL), Spatial Thinking Ability, Geography

\section{Introduction}

One of the goals of learning geography is to provide students with spatial thinking skills. Spatial thinking becomes an important identifier in geography learning activities. The study of geographic phenomena not only explains the existence of a phenomenon and the process of occurrence of these phenomena on the surface of the earth but also the shape, size, direction, pattern of phenomena as well as links with other phenomena. This ability will be very useful for students when it comes to determining or making decisions from things that are very simple to complex related to space or location. But learning geography that has not been able to provide these abilities to students (Setiawan, 2015).

Even if students are optimally included in the learning process, they will be easier to hone their spatial thinking skills, as we know today students have broad insights and good technological mastery. So that makes them sometimes want to try something new through a project to apply their spatial abilities, but with previous learning models these abilities can not be developed. 
Based on observations in the field shows that the spatial thinking ability of students has not shown maximum results, according to the results of interviews with resource persons namely geography subjects in SMA PGRI 2 Palembang revealed that 1) the teacher has used several learning methods but the lecture method is still dominant, 2) students less included in the learning process, 3) the 2017 curriculum has not been implemented effectively.

The use of media in learning requires support from the learning model. The learning model used in this study is project-based learning. Projet baced learning (PPA) or project based is a learning model that involves a project in the learning process. Projects undertaken by students can take the form of individual or group projects and are carried out within a certain period of time collaboratively, producing a product, the results of which will then be displayed and presented.

Project based learning (PPA) is a learning model where students are invited to develop their own abilities by creating a project in learning activities, so that they will automatically develop their research abilities, creativity and critical thinking they will be created using the learning model this project based learning (PPA). Where to complete a project requires effort and hard work as well as working cooperatively with groups. Students are also invited to be able to read every possibility in running a project so that they are able to complete the project (activity) properly. The use of Project Based Learning (PPA) that teachers use in learning is expected to be able to improve students' spatial thinking skills towards Geography learning (Hamzah, 2015).

Based on the above problems, the researcher is interested in conducting research with the title "The Effect of Project Based Learning (PPA) Learning Model on Spatial Thinking Ability in Class X Geography Subjects at SMA PGRI 2 Palembang '."

\section{Research Methods}

To determine the effect of Project Based Learning (PPA) on the ability to think spatially, the researchers used the Experimental method. "The experimental method is a research model used to look for the effect of certain treatments on others under controlled conditions" (Sugiyono, 2016:72).

The population in this study were all students of class X IPS consisting of 4 classes with a total of 143 students. While the sample in this study there were two classes selected by cluster random sampling technique from the population, namely students of class X IPS 1 as an experimental class totaling 36 students and class X IPS 2 as a control class of 36 
students. So the number of samples in this study were 72 students. The experimental class is a class that is treated using the project based learning (PPA) learning model while the control class is a class that is not treated using the project based learning (PPA) learning model but instead uses conventional methods. This research was conducted on 10 April 2019-26 April 2019. There are 2 techniques in collecting data, namely by using tests and documentation. The data analysis technique in this research is by using t-test.

\section{Results and Discussion}

This research was conducted for 2 (two) weeks with 8 (eight) meetings. In this study Class X IPS 1 was given the treatment of learning by using a project based learning (PJBL) learning model with 3 (three) meetings, whereas in Class X IPS 2 was given the treatment of lecture learning with 3 (three) meetings. For the 4th meeting, a test was conducted to determine the spatial ability of the two class groups.

From the results of research conducted by researchers using a project based learning model (PPA) obtained spatial ability of students of class X IPS 1 is better than class X IPS 2 . Can be seen from the average value of student test results taught by using a project based learning model (PPA) of 76.02 and the average value of student test results taught using the lecture learning model of 61.72. This is because learning by using a project based learning model (PPA) is more effective and efficient than the lecture learning model. So, the results of the final test scores of students in class X IPS 1 taught using the project based learning (PJBL) learning model have increased.

Based on the calculation results obtained for class X IPS 1 normality test data obtained class X IPS $1 \mathrm{Km}=0.02$ while class X IPS $2 \mathrm{Km}=-0.21$ and the price is located between (1) and (1) so that it can be said that class X IPS 1 and class X IPS 2 data are normally distributed. Then the calculation results for the homogeneity test of the data can be concluded that, $\mathrm{x} 2$ count $<\mathrm{x} 2$ table or $1.289<3.841$. So the research data obtained from the experimental group and the control group followed a normal and homogeneous distribution. So it can be concluded that the sample comes from the same or similar population. Thus, the research data of the two experimental classes follows a normal and homogeneous distribution. 
After testing the normality and homogeneity of the data, the data that I took came from populations that were normally distributed and the variance in the study was homogeneous, then for the next step, testing the hypotheses using parametric statistics was using the t-test formula.

From the analysis of the subject matter of the atmosphere by applying the project based learning model (PPA) obtained tcount $=8.43$ on the basis of a significant level of 0.05 for 70 $\mathrm{dk}$, obtained ttable $=1.66$, then tcount $>$ ttable is $8.43>1,66$. Based on the hypothesis testing criteria, Ho is rejected and $\mathrm{Ha}$ is accepted, this means that there is an influence of the Project Based Learning (PJBL) learning model on spatial thinking skills in class X Geography subjects at SMA PGRI 2 Palembang.

From the results above shows that the project based learning model (PPA) significantly influences the ability of spatial thinking in class $\mathrm{X}$ geography subjects at SMA PGRI 2 Palembang. This is in accordance with research conducted by Oktavianto, et al. (2017) where the results show that project-based learning assisted by Google Earth has a significant effect on students' spatial thinking skills. Some of the advantages of this learning include: (1) 88\% of students become challenged to solve real problems through project activities, (2) $100 \%$ of students increasingly active in learning, (3) $96 \%$ of students' performance in completing projects more regularly, (4) $100 \%$ of students feel they have more freedom to complete projects, (5) $98 \%$ of students are motivated to compete to produce the best products, and (6) $89 \%$ students experience increased spatial thinking skills.

The results of research by Sarwono, et al (2016) also show that, (1) the project based learning model is very effective in efforts to increase knowledge of natural disasters in Indonesia in class X SMA Negeri 2 Surakarta in learning geography basic competencies of disaster mitigation, (2) Project based learning is very effective in efforts to improve environmental love behavior of class X students of SMA Negeri 2 Surakarta in learning geography on basic competencies in disaster mitigation. Significant influence in the project based learning model (PPA) significantly influences the ability of spatial thinking in class $\mathrm{X}$ geography subjects at SMA PGRI 2 Palembang allegedly due to the following things.

First, students are challenged to create and work on their map project as well as possible, which can be seen from each group trying to produce the best map. Second, students are more active and the learning process can be seen from the participation of each group in implementing their map project. Third, the experimental class students have increased their spatial thinking skills. This study found several weaknesses, namely, it requires a long time 
span to produce the best project and the class is less conducive because students are less conducive in working on the project.

From the analysis and discussion above, it can be concluded that the experimental class applied by the project based learning model (PPA) gets better spatial ability than the control class that does not apply the project based learning model (PPA), especially on the subject of the atmosphere. In addition, the use of project based learning (PPA) which is applied in the experimental class is useful to encourage students to engage in learning, help each other, and provide input and motivate students so that they can improve their spatial thinking skills.

\section{Conclusion and Recommendation}

Based on the results of data analysis and discussion of the effect of project based learning (PPA) learning models on spatial thinking skills in class X geographical subjects at SMA PGRI 2 Palembang, it can be concluded that, the results of data analysis on average results of spatial thinking ability tests of experimental class students 76.02 while the control class averaged 61.72. Based on the results of the t-test obtained tcount $=8.43$ then compared with table $=1.66$, then tcount $>$ ttable is $8.43>1.66$, the hypothesis which states that there is an influence of project based learning (PPA) learning model on spatial thinking ability in class X geographical subjects at SMA PGRI 2 Palembang received (received Ha).

Based on the results of the study, the researcher recommends that future researchers emphasize the ability to think spatially (comparative), hierarchy (level) and analogy (similarity) so that 11 spatial thinking abilities according to Gersmehl and Gersmehl will be known in more detail.

\section{Reference}

Arikunto, Suharsimi. (2017). Prosedur Penelitian Suatu Pendekatan Praktik. Jakarta: Rineka Cipta.

Hamzah, Iqbal Nur, Ali Imron dan Yustina Sri Ekwandari. (2016). Pengaruh Model Project Based Learning (PJBL) Terhadap Peningkatan Motivasi Belajar Sejarah Siswa: Jurnal Pendidikan.

Oktavianto, Dwi Angga, Sumarni dan Budi Handoyo. (2017). Pengaruh Pembelajaran Berbasis Proyek Berbantuan Google Earth Terhadap Keterampilan Berpikir Spasial: Jurnal Teknodik. Volume 21(1):1-11.

Sarwono, Sigit Santoso dan Soegiyanto S.U. (2016). Pengaruh Model Pembelajaran Project Based Learning Terhadap Pengetahuan Bencana Alam Di Indonesia dan Perilaku Cinta 
Lingkungan Hidup Siswa Kelas X SMA N 2 Surakarta Tahun 2015: Jurnal GeoEco. Volume 2(2): 184-197. 